\title{
Analysis of Sorption Properties of Anthrosols in the Park Ludowy in Lublin
}

\author{
Monika Jaroszuk-Sierocińska ${ }^{*}$ \\ 1 Institute of Soil Science, Environment Engineering and Management, University of Life Sciences in Lublin, \\ Leszczyńskiego 7, 20-069 Lublin, Poland \\ * E-mail: monika.jaroszuk@up.lublin.pl
}

\begin{abstract}
The sorption properties of anthropogenic soils, or anthrosols, were examined in the Park Ludowy in Lublin. The test samples were taken from five pedons, from layers 0-25, 25-50 and 50-75 cm. The samples were analyzed in terms of hydrolytic acidity, total exchangeable bases, as well as calculations of cation exchange capacity and basic cations saturation were conducted. The analysis of the chemical properties of the park soils showed the changes resulting from the introduction of anthropogenic material to soil in this case, float earth. It was found that these changes varied within the park. Anthropogenic additions introduced into the soil had a beneficial effect on the hydrolytic acidity, the sum of alkaline cations in the soil, the degree of saturation of the sorption complex with alkaline cations mainly in the root zone of plants.
\end{abstract}

Keywords: sorption properties, anthrosols, urban park

\section{INTRODUCTION}

Green areas in increasingly urbanized cities are becoming an essential element in urban planning. Nowadays, revitalisation and protection of green areas, including historic parks, involves the need to respond to changing spatial conditions [Adamiec and Trzaskowska 2012, Fortuna-Antoszkiewicz 2012]. The negative changes in park soils due to structural degradation and nutrient leaching should be prevented. The comprehensive study of soil in urban areas is one of the main research directions in environmental geochemistry. According to Konstantinova et al. [2019], the geochemistry of urban soils depends on a combination of natural and anthropogenic factors specific to each urban environment. Scharenbrochab et al. [2005] emphasised that as the initial disturbance to the soil environment increases, the impact of urbanisation is reduced by the processes that improve the physical, biological and chemical properties of the soil, and of the soil-forming factors, time plays he most important role in these transformations.
Assessing the quality of soils is not easy because of their complexity as well as the variability of their physical, chemical and biological properties and conditions. The sorption properties of soils play an important role as a factor regulating the leaching of nutrients from the soil, determining the efficiency of fertilisation and regulating plant nutrition [Meller et al., 2013]. Greinert [2009] believes that improving the sorption capacity of urban soils reduces the bioavailability of accumulated pollutants and is a prerequisite for the maintenance of urban green areas. Siuta [1995] reported that soil resistance to degradation is dependent on the sorption capacity of the soil and the content of alkaline cations in the soil. An important aspect in soil quality research is the relationship between the content of contaminants retained by the solid phase of the soil and the concentration of the contaminant in the soil solution.

The content of pollutants present in the soil solution is of great ecological importance due to the possibility of certain components being absorbed by plant roots. Contaminants such as e.g. heavy metals and PAHs, due to their properties, 
pose a high potential risk to human health and may adversely affect the biotic elements of the soil environment.

The studies related to the assessment of the chemical properties of urban park soils are essential for taking the protective measures against the degradation resulting from inappropriate management.

The aim of the study was to evaluate the sorption properties of the anthrosols of the Park Ludowy before restoration, showing the current state of the soil and paying attention to the transformation of the soil cover, related to the park use and restoration works.

\section{MATERIAL AND METHODS}

Park Ludowy was established in the 1950s, it was one of the largest (31 hectares) and most important green areas in Lublin. It was established on wetlands on the right bank of the Bystrzyca River. The park was designed by an outstanding architect, Władysław Niemirski, and served primarily aesthetic, recreational and leisure functions.
In the 1980s, the significance of the park began to decline and it was subject to destruction and devastation. In addition, the lack of land reclamation and the dumping of soil from the settlers of the Lublin Sugar Factory into the park led to unfavourable changes in the root zone of the trees, causing their death. About 600 trees were cut down at that time. Attempts have been made to restore the beauty of the park, in the years 20002001 drainage works were carried out, which resulted in an improvement in the water properties of the soil, and in 2002, in order to make this not very representative place more attractive, the first facility of the Lublin International Fair was built in the park. Currently, the park is in the vicinity of other recreational facilities such as Arena Lublin, the Olympic swimming pool Aqua Lublin, the athletics stadium at al. Zygmuntowskie and the Lublin Trade Fair (Fig. 1). In 2015, a project to revitalise the Park Ludowy was developed on the basis of a community concept and in collaboration with its authors. Even at the stage of design works, the idea was presented to residents and submitted for public consultation. The revitalisation began in 2019 and included comprehensive

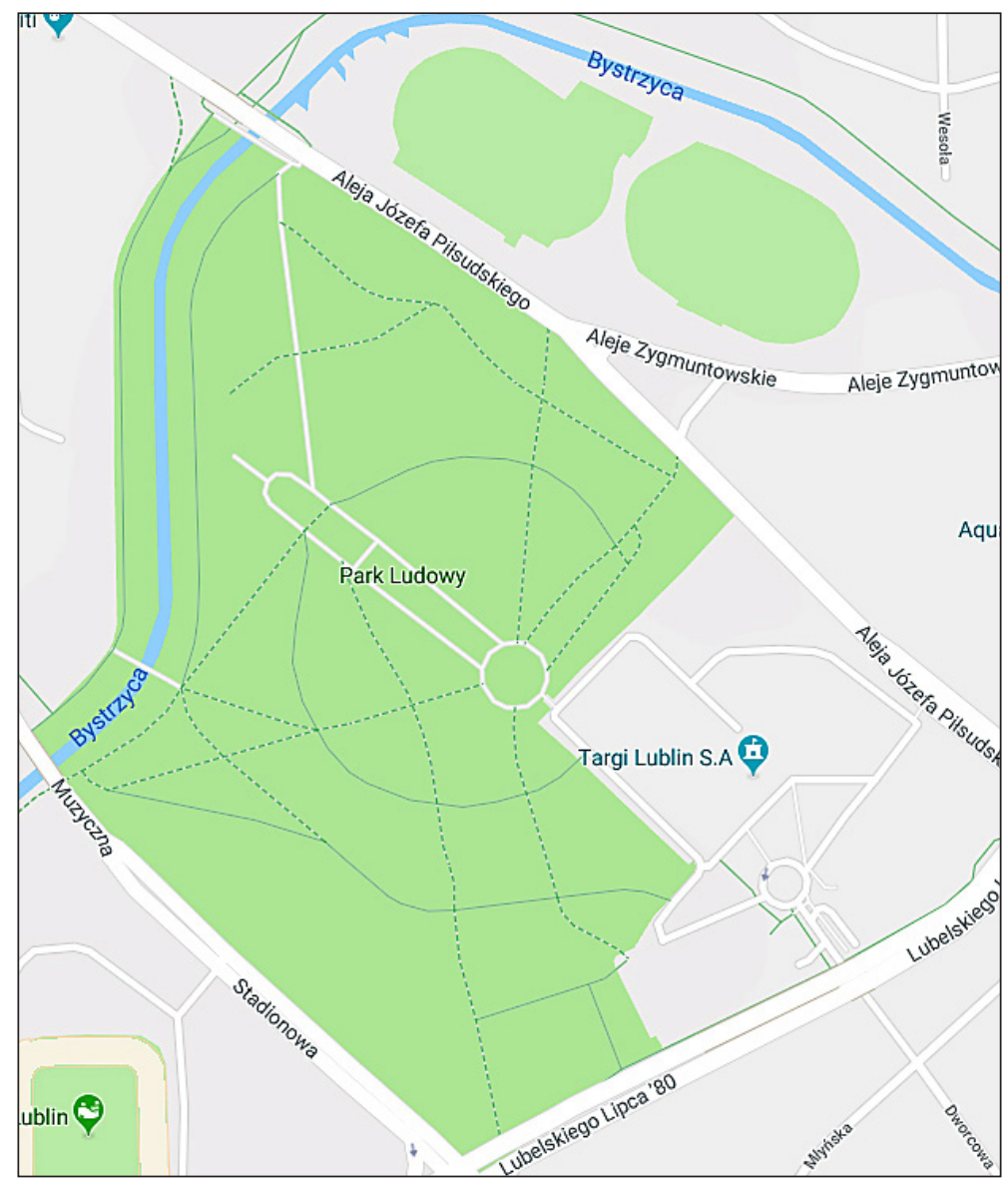

Figure 1. Map of the Park Ludowy in Lublin [https://www.google.pl/maps/@51.2353739,22.5598855,16.33z] 
landscaping of the greenery, as well as creation of didactic gardens and educational nature trails. The boundaries of the Park Ludowy are defined by al. Józefa Piłsudskiego to the east, ul. Lubelskiego Lipca 80 to the south, ul. Stadionowa to the west and the Bystrzyca River to the north.

The main objective of the Park Ludowy revitalization is to protect biodiversity, to restore natural resources, to organize build recreational and educational infrastructure and to make the park space available to residents while preserving and promoting the natural heritage. The activities undertaken within the framework of the investment are primarily aimed at effective protection of the ecosystems existing in the Park Ludowy, stopping the degradation of soil and urban greenery and contributing to shaping the pro-ecological attitudes in society. The renewal of the greenery in the park is intended not only to prevent the division of green areas, but also to create links to existing natural zones in the valley of the Bystrzyca River. [Resolution of the City Council 2017].

The anthropogenic soils of the Park Ludowy - one of the most important parks in the centre of Lublin - were studied. According to the IUSS Working Group WRB [2015], these soils are classified as Terric Anthrosols, and according to the Systematics of Soils of Poland [PTGleb. 2019], as anthropogenic soils order, culturoterrestrial soil type, rigosols subtype. Three of the samples analysed met the organic material criterion [IUSS Working Group WRB 2015], these were the samples from the $50-75 \mathrm{~cm}$ layer of Pedons I, III and $\mathrm{IV}$, containing $\geq 20 \mathrm{~g} \cdot 100^{-1} \cdot \mathrm{g}^{-1}$ of organic carbon. $\mathrm{CaCO}_{3}$, was found in most samples, only the samples with the highest organic carbon content (50-75 cm layer of pedons I and IV) and 0-25 cm layer of pedon IV were carbonate-free. Calcium carbonate was often present in the form of highly fragmented snail shells [Jaroszuk-Sierocińska, Słowińska-Jurkiewicz 2018) (Tab. 1).

The soil pits were located on a line passing from west to east, from the embankment of the Bystrzyca River, through the central part of the park. The geographical coordinates of the pits are as follows: pedon I $-51^{\circ} 14^{\prime} 9.27^{\prime \prime} \mathrm{N}, 2^{\circ} 33^{\prime} 30.7^{\prime \prime} \mathrm{E}$; pedon II $-51^{\circ} 14^{\prime} 9.13^{\prime \prime} \mathrm{N}, 2^{\circ} 33^{\prime} 35.82^{\prime \prime} \mathrm{E}$; pedon III $-51^{\circ} 14^{\prime} 8.88^{\prime \prime} \mathrm{N}, 22^{\circ} 33^{\prime} 41.44^{\prime \prime} \mathrm{E}$; pedon IV $-51^{\circ} 14^{\prime} 9.29^{\prime \prime} \mathrm{N}, 22^{\circ} 33^{\prime} 46.01^{\prime \prime} \mathrm{E}$; pedon V $51^{\circ} 14^{\prime} 11.34^{\prime \prime} \mathrm{N}, 22^{\circ} 33^{\prime} 52.42^{\prime \prime} \mathrm{E}$. The samples for soil sorption properties were taken in triplicate from five pedons, from layers of $0-25,25-50$ and $50-75 \mathrm{~cm}$.
The following determinations have been made in accordance with the methodology adopted in soil science studies: the organic carbon content was determined using an organic carbon analyser - (TOC) Shimadzu Corporation using the SSM5000A solid sample combustion unit, the soil reaction ( $\mathrm{pH}$ in $1 \mathrm{~mol} \mathrm{KCl-dm-3)}$ was tested potentiometrically, the content of calcium carbonate $\left(\mathrm{CaCO}_{3}\right)$ was measured using the Scheibler's method, hydrolytic acidity $(\mathrm{Hh})$ was measured using the Kappen's method, the sum of base cations (S) in non-carbonate samples using the Kappen's method, and in carbonate samples using the Pallmann's method. Cation exchange capacity(T) and the degree of saturation of the sorption complex with basic cations were calculated $\left(\mathrm{V}_{\mathrm{s}}\right)$. The results of the analysis of sorption properties of the Park Ludowy soils were statistically analysed. An analysis of variance was performed for double orthogonal classification (pedon $\times$ layer). The significance of differences between the means was determined using Tukey's test $(\alpha=0.05)$.

\section{RESULTS AND DISCUSSION}

The present soil cover of the Park Ludowy was created as a result of mixing peat and silt material with materials of anthropogenic origin. In the studied soils of the Park Ludowy, the introduction of float soil and loess had a significant effect on the sorption properties, which varied the basic parameters of the soil material, both between and within pedons [Jaroszuk-Sierocińska and Słowińska-Jurkiewicz 2018]. The authors

Table 1. Basic chemical properties of antropogenic soils in Park Ludowy

\begin{tabular}{|c|c|c|c|c|}
\hline \multirow[t]{2}{*}{ Pedon } & \multirow{2}{*}{$\begin{array}{c}\text { Layer } \\
(\mathrm{cm})\end{array}$} & $\begin{array}{c}\text { Organic } \\
\text { carbon }\end{array}$ & $\mathrm{CaCO}_{3}$ & \multirow{2}{*}{$\begin{array}{c}\text { Reaction } \\
\left(\mathrm{pH}_{\mathrm{KCl}}\right)\end{array}$} \\
\hline & & \multicolumn{2}{|c|}{$\mathrm{g} \cdot 100^{-1} \cdot \mathrm{g}^{-1}$} & \\
\hline I & $\begin{array}{c}0-25 \\
25-50 \\
50-75\end{array}$ & $\begin{array}{c}15.00 \\
8.04 \\
28.76 \\
\end{array}$ & $\begin{array}{c}20.76 \\
18.84 \\
0.00 \\
\end{array}$ & $\begin{array}{l}6.9 \\
6.9 \\
6.3 \\
\end{array}$ \\
\hline II & $\begin{array}{c}0-25 \\
25-50 \\
50-75\end{array}$ & $\begin{array}{c}11.16 \\
2.46 \\
14.64 \\
\end{array}$ & $\begin{array}{l}8.34 \\
8.28 \\
5.80 \\
\end{array}$ & $\begin{array}{l}6.8 \\
6.8 \\
6.9 \\
\end{array}$ \\
\hline III & $\begin{array}{c}0-25 \\
25-50 \\
50-75\end{array}$ & $\begin{array}{c}8.64 \\
3.96 \\
20.82 \\
\end{array}$ & $\begin{array}{l}2.98 \\
2.51 \\
3.59\end{array}$ & $\begin{array}{l}6.9 \\
7.1 \\
6.6\end{array}$ \\
\hline IV & $\begin{array}{c}0-25 \\
25-50 \\
50-75\end{array}$ & $\begin{array}{c}2.94 \\
3.72 \\
39.12\end{array}$ & $\begin{array}{l}0.00 \\
4.62 \\
0.00\end{array}$ & $\begin{array}{l}6.7 \\
7.2 \\
6.1\end{array}$ \\
\hline V & $\begin{array}{c}0-25 \\
25-50 \\
50-75\end{array}$ & $\begin{array}{l}4.22 \\
1.01 \\
9.54\end{array}$ & $\begin{array}{c}2.54 \\
7.20 \\
13.64\end{array}$ & $\begin{array}{l}7.2 \\
7.2 \\
7.1\end{array}$ \\
\hline
\end{tabular}


[2018] showed that the addition of earthy materials reduced the organic carbon content of the park soils, but this was compensated by an increased proportion of fine mineral particles. Multiple anthropogenic transformations have resulted in transformations of both physical and chemical properties of these soils. The natural use of waste, such as floating soil, consists in using it to shape the biologically active surface of the earth, primarily to maintain and increase soil fertility [Siuta 2001]. Resztel et al. [1998] showed that floatation soil can be used to improve the richness of medium and good formations located in the vicinity of sugar factories. The results of their experiments show that the application of soil to peat-moorsh soils increased crop yields. The addition of the floating soil significantly improved the physical properties and $\mathrm{pH}$ of the soil, as well as its abundance. It follows that the agricultural use of floatation soil is an appropriate use for this waste. As the soil becomes richer in highly sorptive materials, its sorption properties are changed. Bielińska and Mocek [2010] stress that soil sorption in urban park areas is improved by bringing in organic matter from waste such as municipal waste composts or sewage sludge. Given the important role of soils in the surrounding space, Jakubus [2015] indicated changes in soil properties expressed by an increase in $\mathrm{pH}$ values and a favourable balance of organic matter. These phenomena should be seen as positive processes of importance for both agricultural production and environmental protection. In the studied soils, the $\mathrm{pH}$ of the majority of samples was neutral, except for organic and non-carbonate material from the $50-75 \mathrm{~cm}$ layer of pedons I and IV, where it was weakly acidic (Table 1).

The hydrolytic acidity in the park soils ranged from $1.20 \mathrm{cmol}(+) \cdot \mathrm{kg}^{-1}$ to $3.90 \mathrm{cmol}(+) \cdot \mathrm{kg}^{-1}$ (Table 2). Its highest value was found in the superficial layer $(0-25 \mathrm{~cm})$ of pedon III, while the lowest value was found in the middle layer $(25-50 \mathrm{~cm})$ of pedon $\mathrm{V}$. In most pedons, the values of the analysed trait were similar, in the surface layers they were higher than in the middle layers, and then they increased again in the layers at the depth of 50-75 cm. Only in pedon II there was a decrease in hydrolytic acidity with depth. The differences analysed were statistically significant. The results of hydrolytic acidity show the changes occurring in the soils, a similar relationship as noted in the $\mathrm{pH}$ of the soils studied
(Table 1). A significant increase in hydrolytic acidity was found in the soils in which the $\mathrm{pH}$ value decreased.

In anthropogenic soils, elevated values for characteristics such as total base cations, saturation of the sorption complex with bases and reaction illustrate the typical phenomenon of mixing construction waste and lime-containing materials into the soil.

The properties of urban soils are largely shaped by reclamation measures carried out before the establishment of green areas [Greinert 2009]. Before reclamation, the sum of base cations in the soils of the Park Ludowy was quite high, ranging between 41.80 and $49.00 \mathrm{cmol}(+) \cdot \mathrm{kg}^{-1}$ (Table 2). Both these values occurred in pedon $\mathrm{V}$ in layers $0-25 \mathrm{~cm}$ and $50-75 \mathrm{~cm}$. In the surface layers of most pedons, the values of the analysed trait were lower and increased with depth. Only in pedon III the sum of base cations in the middle layer was slightly higher $\left(48.80 \mathrm{cmol}(+) \cdot \mathrm{kg}^{-1}\right)$ than in the surface layer $\left(48.40 \mathrm{cmol}(+) \cdot \mathrm{kg}^{-1}\right)$. The smallest statistically significant difference at a significance level of $\alpha=0.05$ between the layers was $0.329 \mathrm{cmol}(+) \cdot \mathrm{kg}^{-1}$.

The higher capacity of the surface layers is typical of urban soils. In deeper layers in the soil profile, the sorption capacity often depends on the overlying organic and waste layers of porous materials [Greinert et al. 2013]. In a study by Bielińska and Mock [2010], the sorption properties of soils in urban parks were different, associated with asynchronous distribution of soil material during urban transformations in these areas. According to these authors [2010], the addition of organic compounds and mineral materials with significant sorption capacity to the soil environment under conditions of long-term urbanization is associated with the use of urban soils, moreover it involves the addition of both natural and anthropogenic substrates differing in composition, quantity, origin, and also in the way they are spatially displaced.

The cation exchange capacity of park soils ranged from $43.30 \%$ in pedon $V$ to $52.35 \%$ in pedon II. In three pedons (I, IV and V) the values of the analysed property increased with depth, in the remaining two (II and III) the sorption capacity decreased with the depth of the profile and an increase of this property in the layer at the depth of 50-75 cm was recorded only in pedon III (Table 2). 
Table 2. Sorption properties of soils

\begin{tabular}{|c|c|c|c|c|c|}
\hline \multirow{2}{*}{ Pedon } & \multirow{2}{*}{ Layer (cm) } & $\mathrm{H}_{\mathrm{h}}$ & $S$ & $T$ & \multirow{2}{*}{$\begin{array}{l}V_{s} \\
\%\end{array}$} \\
\hline & & \multicolumn{3}{|c|}{$\mathrm{cmol}(+) \cdot \mathrm{kg}^{-1}$} & \\
\hline I & $\begin{array}{c}0-25 \\
25-50 \\
50-75\end{array}$ & $\begin{array}{l}3.03 \\
2.25 \\
3.22\end{array}$ & $\begin{array}{l}47.22 \\
48.28 \\
48.60\end{array}$ & $\begin{array}{l}50.25 \\
50.53 \\
51.82\end{array}$ & $\begin{array}{l}93.962 \\
95.542 \\
93.780\end{array}$ \\
\hline II. & $\begin{array}{c}0-25 \\
25-50 \\
50-75\end{array}$ & $\begin{array}{l}3.75 \\
3.00 \\
2.70\end{array}$ & $\begin{array}{l}48.60 \\
48.40 \\
48.40\end{array}$ & $\begin{array}{l}52.35 \\
51.40 \\
51.10\end{array}$ & $\begin{array}{l}92.838 \\
94.159 \\
94.709\end{array}$ \\
\hline III & $\begin{array}{c}0-25 \\
25-50 \\
50-75\end{array}$ & $\begin{array}{l}3.90 \\
1.95 \\
3.00\end{array}$ & $\begin{array}{l}48.40 \\
48.80 \\
48.42\end{array}$ & $\begin{array}{l}52.30 \\
50.75 \\
51.42\end{array}$ & $\begin{array}{l}92.545 \\
96.158 \\
94.167\end{array}$ \\
\hline IV & $\begin{array}{c}0-25 \\
25-50 \\
50-75\end{array}$ & $\begin{array}{l}2.55 \\
2.10 \\
3.00\end{array}$ & $\begin{array}{l}44.20 \\
48.60 \\
48.80\end{array}$ & $\begin{array}{l}46.75 \\
50.70 \\
51.80\end{array}$ & $\begin{array}{l}94.545 \\
95.859 \\
94.199\end{array}$ \\
\hline V & $\begin{array}{c}0-25 \\
25-50 \\
50-75\end{array}$ & $\begin{array}{l}1.50 \\
1.20 \\
2.25\end{array}$ & $\begin{array}{l}41.80 \\
48.60 \\
49.00\end{array}$ & $\begin{array}{l}43.30 \\
49.80 \\
51.25\end{array}$ & $\begin{array}{l}96.546 \\
97.590 \\
95.595\end{array}$ \\
\hline $\begin{array}{l}\text { I } \\
\text { II } \\
\text { III } \\
\text { IV } \\
\text { V }\end{array}$ & Means for pedons & $\begin{array}{l}2.837 \\
3.152 \\
2.950 \\
2.551 \\
1.650\end{array}$ & $\begin{array}{l}48.031 \\
48.467 \\
48.541 \\
47.201 \\
46.433\end{array}$ & $\begin{array}{l}50.868 \\
51.619 \\
51.491 \\
49.752 \\
48.083\end{array}$ & $\begin{array}{l}94.428 \\
93.902 \\
94.289 \\
94.868 \\
96.577\end{array}$ \\
\hline Means for layers & $\begin{array}{c}0-25 \\
25-50 \\
50-75\end{array}$ & $\begin{array}{l}2.946 \\
2.101 \\
2.837\end{array}$ & $\begin{array}{l}46.046 \\
48.536 \\
48.622\end{array}$ & $\begin{array}{l}48.992 \\
50.637 \\
51.459\end{array}$ & $\begin{array}{l}94.087 \\
95.862 \\
94.490\end{array}$ \\
\hline \multirow{3}{*}{$\begin{array}{l}\operatorname{NIR}(\alpha=0,05) \\
\operatorname{LSD}(\alpha=0.05)\end{array}$} & Pedon $\times$ layer & 0.569 & 1.098 & 1.098 & 1.345 \\
\hline & Pedons & 0.258 & 0.499 & 0.499 & 0.611 \\
\hline & Layers & 0.170 & 0.329 & 0.329 & 0.403 \\
\hline
\end{tabular}

Explanations: $\mathrm{H}_{\mathrm{h}}-$ hydrolytic acidity, $\mathrm{S}-$ sum of exchangeable cations, $\mathrm{T}$ - total sorption capacity, $\mathrm{V}_{\mathrm{s}}-$ degree of basic cations saturation

A very important criterion for changes in the chemical properties of anthropogenic soils is the degree of saturation with alkaline cations. Konecka-Bentley et al. [1984] pointed out already in the 1980s that in chemically and geomechanically transformed soils the degree of base saturation reached $100 \%$ at alkaline $\mathrm{pH}$ and decreased to $90 \%$ further down in the profile. These authors showed that in urban soils with little transformation (large parks), the degree of base saturation was $60 \%$ in the humus level and increased up to $80 \%$ in the depth of the profile. In all the studied pedons of the Park Ludowy, the degree of saturation with alkaline cations was very high and varied on average from $93.902 \%$ in pedon II to $96.577 \%$ in pedon $\mathrm{V}$ and remained at the same level in all layers (from $94.087 \%$ to $95.862 \%$ ). Within the layers in particular pedons, the highest degree of saturation with alkaline cations was observed in the second layer $(25-50 \mathrm{~cm})$ of pedon $\mathrm{V}$ $-97.590 \%$, while the lowest was in the first layer $(0-25 \mathrm{~cm})$ of pedon III $-92.545 \%$. Such values may occur at high intensity of anthropogenic factors and high degree of soil transformation and the abundance of alkaline cations in deeper layers may be higher than in the surface level. The analysis of variance showed statistical significance of the studied trait.

From the data discussed, it is evident that the anthropogenic factors that have influenced the soils of the Park Ludowy, such as the introduction of floatation soil and loess, have played a significant role in transforming soil processes, resulting in differences in their sorption properties, nutrient content, as well as in the structure of the soil profile.

\section{CONCLUSIONS}

The heterogeneous structure of the park showed that the different anthropogenic soils create new habitats and conditions favourable to the preservation of natural vegetation. Anthropogenic additives introduced into the soil in the form of float soil and loess had a beneficial effect on the sorption properties of soils in the root zone of plants. Hydrolytic acidity and total alkaline cations showed large or significant variation both with pedon and depth of layer. Cation exchange capacity and the degree of base cation saturation of the anthropogenic park soils remained very high and were characteristic 
of highly chemically transformed soils. After the revitalization of the park and before any new planting, special attention should be paid to the chemical properties of the soil cover and especially to its very strong sorption capacity.

\section{REFERENCES}

1. Adamiec P., Trzaskowska E. 2012. The diagnosis and guidelines for development of green estates in Lublin. Teka Kom. Arch. Urb. Stud. Krajobr. - OL PAN. VIII/1, 7-18. (in Polish)

2. Bielińska J.E., Mocek A. 2010. Sorption properties and enzymatic activity of municipal park soils in regions of varying impact of anthropologic pressure. Journal of Research and Applications in Agricultural Engineering, 55(3), 20-23. (in Polish)

3. Fortuna-Antoszkiewicz B., Gawłowska A., Łukaszkiewicz J., Rosłon-Szeryńska E. 2012. Problems of restoration and preservation downtown historical parks on the example of Garden Krasiński in Warsaw. Architektura, 19(109), 145-166. (in Polish)

4. Greinert A. 2009. Sorption capabilities improvement as a condition of maintaining the municipal green in good state. Rocz. Glebozn., 60, 3, 75-83. (in Polish)

5. Greinert A., Fruzińska R., Kostecki J. 2013. Urban soils in Zielona Góra. In: Charzyński P, Hulisz P, Bednarek R (eds) Technogenic soils of Poland. Polish Society of Soil Science, Toruń, 31-54.

6. IUSS Working Group WRB. 2014. World Reference Base for Soil Resources 2014, update 2015. International soil classification system for naming soils and creating legends for soil maps. World Soil Resources Reports, FAO, Rome, 106.

7. Jakubus M. 2015. Changes of chosen soil properties as a consequence of urbanization transformation in the city space of Poznań. Problemy Rozwoju Miast Kwartalnik Naukowy Instytutu Rozwoju Miast, Rok XII, Zeszyt IV/2015, 19 - 25, (in Polish)

8. Jaroszuk-Sierocińska M., Słowińska-Jurkiewicz A. 2018. Physical status of soils of Park Ludowy in
Lublin. Acta Agrophys., 25(2), 213-225. (in Polish)

9. Konecka-Betley K., Janowska E., Łuniewska-Broda J., Szpotański M. 1984. Prelimary classification of soils of the Warsaw aglomeration. Rocz. Glebozn, 35, 151-163. (in Polish)

10. Konstantinova E., Minkina T., Sushkova S., Konstantinov A., Rajput V.D., Sherstnev A. 2019. Urban soil geochemistry of an intensively developing Siberian city: A case study of Tyumen, Russia. Journal of Environmental Management, 239, 366-375

11. Meller E., Niedźwiecki E., Malinowski R., Kubus M., Podlasiński M. 2013. Suitability of former arable land for extension of Dendrological Garden collection in Przelewice Part II. Sorption properties and chemical element content. Folia Pomer. Univ. Technol. Stetin., Agric., Aliment., Pisc., Zootech., 305(27), 51-66. (in Polish)

12. Polskie Towarzystwo Gleboznawcze. 2019. Polish Soil Classification. Wyd. VI. Wydawnictwo Uniwersytetu Przyrodniczego we Wrocławiu. (in Polish)

13. Resztel R., Klikocka H., Reszel H., Głowacka A. 1998. Agricultural utility of floating soil. Ekoinżynieria. Polskie Towarzystwo Inżynierii Ekologicznej, 6, 17-19. (in Polish)

14. Scharenbrochab B.C., Lloydac J.E., Johnson-Maynardac J.L. 2005. Distinguishing urban soils with physical, chemical, and biological properties. Pedobiologia, 49, 283-296.

15. Siuta J. 1995. Soil - condition and threat diagnosis. IOŚ Warszawa, 219. (in Polish)

16. Siuta J. 2000. Protection of the earth's surface condition and necessary actions. Inżynieria Ekologiczna, 1, 158-183. (in Polish)

17. Siuta J. 2011. Protection and renewal biologically active the surface of the earth and the economy waste. Ochrona Środowiska i Zasobów Naturalnych, 46, 73-82. (in Polish)

18. Resolution of the City Council No 735/ XXIX/2017, Lublin., 2017. https://bip2.lublin.eu/ bip/um. (dostęp: 15.03. 2020). (in Polish)

19. Map of Park Ludowy in Lublin. 2021. https://www. google.pl/maps/@51.2353739,22.5598855,16.33z, (dostęp: 11.08.2021) (in Polish) 